\title{
STUDI PERUBAHAN DAYA DUKUNG TIANG PANCANG TERHADAP WAKTU BERDASARKAN UJI PEMBEBANAN STATIK DAN DINAMIK
}

\author{
Gerraldi Pratama $^{1}$, Aksan Kawanda ${ }^{2}$ dan Hendy Wijaya ${ }^{3}$ \\ ${ }^{1}$ Program Studi Sarjana Teknik Sipil, Universitas Tarumanagara, Jl. Letjen S. Parman No.1 Jakarta \\ Email: gerraldipratama@gmail.com \\ ${ }^{2}$ Program Studi Sarjana Teknik Sipil, Universitas Tarumanagara, Jl. Letjen S. Parman No.1 Jakarta \\ Email: akawanda@geotech-indonesia.com \\ ${ }^{3}$ Program Studi Sarjana Teknik Sipil, Universitas Tarumanagara, Jl. Letjen S. Parman No.1 Jakarta \\ Email: hendyw@ft.untar.ac.id
}

\begin{abstract}
ABSTRAK
Pondasi tiang telah menjadi salah satu pilihan dalam suatu proyek infrastruktur dikarenakan fondasi tiang berfungsi meneruskan beban dari struktur diatasnya menuju lapisan tanah. Salah satu pilihan pondasi tiang adalah pondasi tiang pancang. Dalam proses desain untuk mencari daya dukung pondasi tiang terdapat beberapa kombinasi rumus baik di tanah pasir ataupun lempung, diantaranya adalah Meyerhof 1976, Lambda, Alpha, Beta, Tomlinson, Coyle Castello, Meyerhof 1956 dan deRuiter\&Beringen. Hasil daya dukung dari rumus tersebut perlu diuji dilapangan dengan pembebanan statik dan dinamik. Kemudian untuk tiang pancang terdapat faktor yang mempengaruhi daya dukung salah satunya faktor soil setup. Hasil Analisis menunjukan tiang pancang yang terpasang pada tanah di daerah Cirebon dengan ukuran $400 \mathrm{~mm}$, $600 \mathrm{~mm}$ dan $762 \mathrm{~mm}$ dengan jenis spun pile dan steel pipe pile memiliki kecenderungan peningkatan daya dukung dengan kisaran 18-33\% berdasarkan uji pembebanan statik dan dinamik selama 7 hari, dan memiliki peningkatan sebesar $10 \%$ selama 92 hari setelahnya. Analisis rumus pendekatan peningkatan daya dukung Skov\&Denver juga menunjukan dapat dipakai pada kondisi tanah Cirebon. Sedangkan rumus perhitungan teoritis dapat digunakan dalam perhitungan daya dukung tiang, dapat sesuai dengan pembebanan statik dan dinamik pada waktu yang pendek ataupun hasil perhitungan teoristis akan tercapai dalam waktu yang lama terlihat dari pola yang terbentuk.
\end{abstract}

Kata kunci: pondasi tiang, peningkatan daya dukung, soil setup, spun pile, steel pipe pile

\section{PENDAHULUAN}

\section{Latar belakang}

Perkembangan bidang konstruksi di Indonesia sedang mengalami percepatan dikarenakan pemerintah menerapkan proyek strategis nasional sebagai langkah konkrit dalam percepatan pembangunan. Hal ini didukung dengan indeks pembangunan infrastruktur Indonesia yang dimuat dalam The Global Competitiveness Report pada tahun 2017-2018 mengalami peningkatan menjadi peringkat ke-52 dibandingkan tahun 2015 yang berada pada peringkat ke-62.

Pembangunan konstruksi yang terdapat pada proyek strategis nasional tersebut, antara lain, jalan nasional, tol, bendungan, pembangkit listrik, bandara, pelabuhan, LRT, MRT, dan kereta bandara

Indonesia negara yang wilayahnya terdiri dari gugusan pulau tentunya memiliki garis pantai yang panjang sehingga pembangunan infrastruktur di dekat pantai atau laut tentunya menjadi pilihan bukan hanya hunian namun juga sektor industri, salah satunya karena akses transportasi yang mudah dari laut untuk distribusi barang dan bahan baku.

Dalam pembangunan infrastruktur yang telah disebutkan diatas, fondasi merupakan elemen penting yang menjadi keberhasilan suatu proyek konstruksi, dikarenakan fondasi berfungsi meneruskan beban dari struktur diatasnya menuju lapisan tanah. Jenis tanah pada pesisir pantai wilayah di Indonesia, terutama pada pesisir pantai utara Pulau Jawa dan peruntukan bangunan diatasnya yang beragam besar bebannya membuat pondasi tiang menjadi salah satu pilihan dalam suatu proyek infrastruktur.

Bukan hanya permasalahan dalam desain daya dukung, namun terdapat juga perbedaan metode pelaksanaan di lapangan serta sifat dan parameter tanah yang memiliki karakteristik dan perilakunya sendiri terhadap pondasi tiang membuat desain dari daya dukung pondasi tiang dengan pengujian di lapangan memiliki selisih nilai.

Oleh karena itu daya dukung fondasi tiang pancang dengan parameter, sifat tanah dan rumus analisis yang berbeda menjadi hal yang dapat dianalisa lebih lanjut. 


\section{Identifikasi masalah}

Berdasarkan latar belakang yang ada dari banyaknya rumus pendekatan untuk desain fondasi tiang pancang, rumus yang dikemukakan para ahli tentunya memiliki kelebihan dan kekurangan pada jenis tanah yang berbeda. Penggunaan rumus pendekatan yang tepat pada jenis tanah spesifik dapat membuat daya dukung fondasi tiang di lapangan akan sesuai dengan perencanaan fondasi.

\section{Batasan masalah}

Batasan - batasan masalah dalam penelitian ini adalah:

1. Penggunaan fondasi tiang pancang berjenis spun pile dan steel pipe pile.

2. Ukuran fondasi tiang pancang berdiameter 400, 600 dan 762 milimeter.

3. Pengujian pembebanan tiang pancang menggunakan metode pembebanan statik dan pembebanan dinamik

4. Mempertimbangkan faktor soil setup.

\section{Rumusan masalah}

Rumusan masalah yang akan dibahas dalam penelitian ini adalah:

1. Analisis daya dukung fondasi tiang pancang terhadap waktu.

2. Analisis rumus perhitungan daya dukung aksial fondasi tiang pancang dengan uji pembebanan statik dan dinamik.

\section{Tujuan penelitian}

Tujuan dari penelitian ini adalah:

1. Untuk mengetahui daya dukung fondasi tiang pancang terhadap waktu

2. Untuk mengetahui besaran nilai daya dukung tiang pancang dan perbandingannya terhadap nilai pengujian di lapangan.

\section{DASAR TEORI}

\section{Daya dukung aksial pondasi tiang pancang}

Daya dukung aksial pada tiang pancang merupakan kemampuan tiang pancang menahan gaya aksial yang dibebani dari atasnya menuju ke lapisan tanah, kemampuan dari tiang menahan beban dipengaruhi oleh daya dukung tanah pada fondasi tiang ditempatkan. Daya dukung aksial tiang pancang didapatkan dari akumulasi dua komponen yaitu gaya gesekan selimut tiang (skin friction) dan gaya perlawanan pada ujung tiang (end bearing).

Sebuah tiang dapat dikatakan tiang tahanan selimut jika daya dukung selimut tiang lebih dominan dibandingkan daya dukung ujung tiang atau ujung tiang tidak mencapai tanah keras. Sebaliknya jika sebuah fondasi tiang ujungnya mencapai lapisan tanah keras atau batuan maka dapat dikatakan sebagai sebuah tiang tahanan ujung (Tomlinson, 1994).

Terdapat beberapa rumus yang dapat digunakan untuk menghitung daya dukung tiang pada tanah pasir maupun tanah lempung seperti yang terdapat di dalam (Rahardjo, 2013), diantaranya adalah Meyerhof 1956, Meyerhof 1976, Lambda, Alpha, Beta, Tomlinson, (Coyle \& Castello), dan deRuiter \& Beringen

\section{Soil setup}

Dalam pelaksanaan pemancangan sebuah tiang ke dalam tanah pada tanah kohesif (clay), tanah akan mengalami perpindahan secara lateral dan akan berpindah ke arah permukaan karena untuk mengimbangi volume tiang yang masuk ke dalam tanah. Pada tanah lempung lunak ketika tiang dipancang, tanah akan mengalami tekanan air pori yang tinggi, tekanan ini akan membuat tegangan efektif yang bekerja pada tiang berkurang sehingga kapasitas aksial tiang akan tereduksi selama pemancangan tiang. Durasi waktu tekanan air pori yang tinggi akan terdisipasi dalam waktu yang berbeda beda bergantung pada jenis tanah yang ada, dan ketika disipasi tekanan air pori selesai maka daya dukung tiang akan kembali meningkat (Tomlinson, 1997).

Terdapat rumus untuk memprediksi perubahan daya dukung tiang akibat soil setup salah satunya rumus yang diberikan oleh Skov and Denver (1988).

$$
\mathrm{Q}_{\mathrm{t}} \quad=\mathrm{Q}_{\mathrm{EOD}}\left[A \cdot \log \left(\frac{t}{t o}\right)+1\right]
$$

dengan $\mathrm{Q}_{\mathrm{t}}=$ kapasitas tiang pada waktu pemancangan tiang, $\mathrm{Q}_{\mathrm{EOD}}=$ kapasitas tiang pada akhir pemancangan, $\mathrm{t}=$ waktu, satuan hari, pada pasir, $\mathrm{A}=0.2$ dan $\mathrm{t}_{0}=0.5$ hari, pada lempung, $\mathrm{A}=0.6$ dan $\mathrm{t}_{0}=1.0$ hari. 


\section{Uji pembebanan statik}

Uji pembebanan statik dapat dilakukan dengan dua metode yaitu dengan metode kentledge dan dengan tiang jangkar. Metode kentledge menggunakan blok beton yang ditumpuk diatas kepala tiang yang ingin diuji tetapi yang telah diberi dongkrak hidrolis sehingga dapat mengatur beban yang ingin diberikan kepada tiang. Pembacaan dial dipasang pada sisi tiang untuk melihat besaran penurunan tiang ketika dibebani. Data yang diambil dalam pembebanan menggunakan metode blok beton ini adalah besarnya penurunan tiang terhadap beban kerja yang diberikan.

Data yang telah didapat kemudian akan diolah menggunakan beberapa metode yang umum digunakan diantaranya adalah metode Chin, Davisson, dan Mazurkiewicz kemudian akan didapatkan data daya dukung tiang berdasarkan interpretasi menggunakan metode tersebut

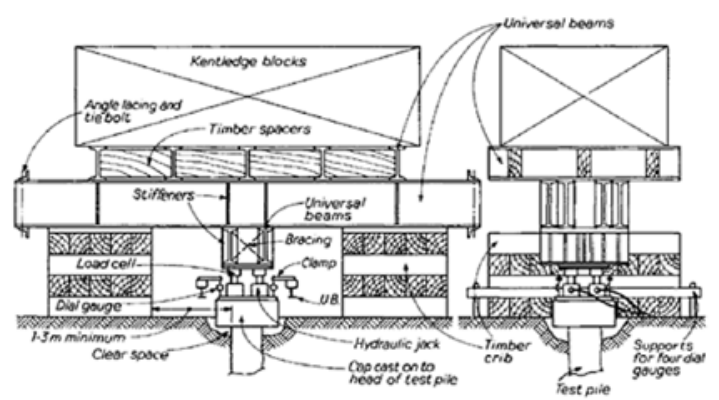

Gambar 1. Metode kentledge (ASTM D1143)

\section{Uji pembebanan dinamik}

Uji pembebanan dinamik dilakukan menggunakan alat pile driving analyzer (PDA) dan drop hammer. Pengujian dengan PDA dilakukan dengan memasang strain transducers dan akselerometer pada sisi tiang yang akan diuji, kemudian data rambatan gelombang akan diterima PDA melalui dua komponen tersebut akibat palu yang dijatuhkan ke atas tiang. Hasil yang diterima PDA akan berupa data rambatan gelombang, kemudia data tersebut diolah melalui program CAPWAP untuk memperoleh data berikut; daya dukung ujung dan selimut tiang, penurunan tiang, transfer beban pada tiang, tegangan tekan dan tarik sepanjang tiang.

\section{Uji pembebanan tiang instrumentasi}

Uji pembebanan tiang instrumentasi dilakukan untuk mengetahui besar pendistribusian beban pada setiap kedalaman tiang yang telah ditentukan sebelum tiang dipasang serta berapa besar pembagian daya dukung antara selimut tiang dan ujung tiang. Instrument yang digunakan dalam uji ini adalah Vibrating Wire Strain Gauges (VWSG) yang terikat pada tiang uji, prinsip kerja alat ini mengukur regangan yang terjadi saat tiang diberi beban dari frekuensi pada getaran kabel yang saling terikat kedua ujungnya.

\section{Studi terdahulu}

Mulyono,dkk (2018) melakukan studi daya dukung tiang terhadap pembebanan statik dan dinamik pada pembangunan gedung di Jakarta, kemudian didapatkan akurasi daya dukung paling dekat sebesar 90.74\% menggunakan rumus Meyerhof (1965).

Beberapa tahun sebelumnya, Widjaja (2007) melakukan studi terhadap dua kasus penggunaan fondasi tiang yaitu di Porto dan di Jakarta pada pembangunan wisma asia II guna menganalisis peningkatan daya dukung fondasi tiang. Dari studi pada kasus tanah pasiran di Porto didapat bahwa daya dukung fondasi tiang dengan diameter $35 \times 35 \mathrm{~cm}^{2}$ dan terpancang sedalam 6 m mengalami peningkatan sebesar 2,6-3,9 kali dengan selang waktu 314 hari setelah pemancangan. Pada studi pembangunan wisma asia II didapat peningkatan daya dukung sebesar 3,0 kali pada tanah lempung selama 8 tahun dengan spesifikasi tiang spun pile berdiameter $50 \mathrm{~cm}$.

\section{METODOLOGI PENELITIAN}

\section{Metode pengumpulan data}

Pada penelitian ini, data tanah dan data tiang pancang yang akan dianalisis berada di daerah Cirebon. Data tanah yang ada berupa data boring, sondir dan hasil uji laboratorium untuk melakukan analisis daya dukung aksial fondasi tiang pancang serta terdapat data uji pembebanan tiang di lapangan secara statik dan dinamik sebagai pembanding hasil daya dukung. 


\section{Metode analisis data}

Berdasarkan data-data yang telah tersedia seperti data boring, sondir dan uji laboratorium maka kemudian akan diolah menjadi parameter tanah yang dipergunakan untuk menghitung daya dukung aksial tiang pancang berdasarkan rumus yang telah dikumpulkan pada studi literatur. Kemudian hasil daya dukung akan dihitung juga berdasarkan kaitannya dengan waktu dengan memperhitungkan faktor soil setup menggunakan rumus empiris yang telah ada. Analisis yang dilakukan akan dilakukan menggunakan program Microsoft excel untuk membantu perhitungan.

Dari hasil daya dukung yang telah dihitung maka akan dibandingkan dengan pengujian yang telah ada di lapangan sehingga didapatkan rumus empiris yang paling mendekati nilainya dengan pelaksanaan.

\section{ANALISIS DATA}

\section{Deskripsi proyek}

Pembangunan proyek ini diantaranya menggunakan pondasi tiang pancang berjenis spun pile dan steel pipe pile. Tiang yang ditinjau pada penelitian ini merupakan tiang yang telah di tes menggunakan uji pembebanan statik dan dinamik serta terpasang instrumen pada tiang berupa Vibrating Wire Strain Gauges (VWSG).

Tabel 1. Data tiang, penyelidikan tanah dan pengujian beban

\begin{tabular}{cccccccc}
\hline \multirow{2}{*}{ Tiang } & \multirow{2}{*}{ Jenis Tiang } & \multirow{2}{*}{ Diameter } & Kedalaman & \multicolumn{2}{c}{ Uji Pembebanan } & \multicolumn{2}{c}{ Data Tanah Terdekat } \\
\cline { 5 - 8 } & & & Tiang & PDA & Statik & SPT & CPT \\
\hline DP04-04 & Spun Pile & $40 \mathrm{~cm}$ & $26,5 \mathrm{~m}$ & EOID, 3 \& 6 Hari & 86 Hari & BA-02 & CPTu-A7 \\
\hline DP04-07 & Spun Pile & $40 \mathrm{~cm}$ & $26 \mathrm{~m}$ & EOID \& 3 Hari & 22 Hari & BA-09 & CPTu-A10 \\
\hline DP06-01 & Spun Pile & $60 \mathrm{~cm}$ & $25,75 \mathrm{~m}$ & EOID, 3 \& 5 Hari & 78 Hari & BA-02 & CPTu-A7 \\
\hline DP06-04 & Spun Pile & $60 \mathrm{~cm}$ & $21,94 \mathrm{~m}$ & EOID \& 4 Hari & 92 Hari & BA-01 & CPTu-A6 \\
\hline DP06-07 & Spun Pile & $60 \mathrm{~cm}$ & $35 \mathrm{~m}$ & EOID, 3 \& 5 Hari & 44 Hari & BA-13 & CPTu-A2 \\
\hline SP-01 & Steel Pipe Pile & $76,2 \mathrm{~cm}$ & $23 \mathrm{~m}$ & EOID, 1, 3 \& 7 Hari & 29 Hari & BA-04 & CPTu-A9 \\
\hline SP-04 & Steel Pipe Pile & $76,2 \mathrm{~cm}$ & 34,75 m & EOID, 1, 3 \& 7 Hari & 24 Hari & BA-04 & CPTu-A9 \\
\hline
\end{tabular}

\section{Analisis daya dukung}

Terdapat 7 tiang yang dilakukan analisis perhitungan daya dukung teoritis yaitu tiang DP04-04, DP04-07, DP06-01, DP06-04, DP06-07, SP-01, SP-04. Perhitungan dukung teoritis dalam penelitian ini menggunakan kombinasi rumus yang dikemukakan oleh Meyerhof 1956, Meyerhof 1976, Lambda, Alpha, Beta, Tomlinson, (Coyle \& Castello), dan deRuiter \& Beringen. Berikut merupakan hasil perhitungan daya dukung teoritis dan pengujian aksial lapangan.

Tabel 2. Resume kapasitas tiang ultimit DP04-04

\begin{tabular}{|c|c|c|c|c|c|c|c|c|c|}
\hline \multirow{4}{*}{ Tiang } & \multicolumn{9}{|c|}{ Kapasitas Tiang Ultimit (ton) } \\
\hline & \multicolumn{5}{|c|}{ Teoritis } & \multicolumn{3}{|c|}{ PDA } & \multirow{2}{*}{$\begin{array}{c}\text { Statik } \\
\text { Hari }\end{array}$} \\
\hline & & & Metode & & & & Hari & & \\
\hline & $\begin{array}{c}\text { Meyerhof } \\
1956\end{array}$ & $\begin{array}{c}\text { Meyerhof } \\
1976 \& \& \\
\text { Lambda }\end{array}$ & $\begin{array}{c}\text { Meyerhof } \\
1976 \text { \& } \\
\text { Alpha }\end{array}$ & $\begin{array}{c}\text { Meyerhof } \\
1976 \text { \& } \\
\text { Beta }\end{array}$ & $\begin{array}{c}\text { deRuiter } \\
\& \\
\text { Beringen }\end{array}$ & EOID & 3 & 6 & 86 \\
\hline $\begin{array}{c}\text { DP04 } \\
-04\end{array}$ & 157,82 & 314,38 & 294,02 & 286,05 & 126,71 & 219,50 & 291,10 & 290,00 & 292,20 \\
\hline
\end{tabular}


Tabel 3. Resume kapasitas tiang ultimit DP04-07

\begin{tabular}{|c|c|c|c|c|c|c|c|c|c|c|c|}
\hline \multirow{4}{*}{ Tiang } & \multicolumn{11}{|c|}{ Kapasitas Tiang Ultimit (ton) } \\
\hline & \multicolumn{8}{|c|}{ Teoritis } & \multicolumn{2}{|c|}{ PDA } & Statik \\
\hline & \multicolumn{8}{|c|}{ Metode } & \multicolumn{2}{|c|}{ Hari } & Hari \\
\hline & $\begin{array}{c}\text { Meyerhof } \\
1956\end{array}$ & $\begin{array}{c}\text { Meyerhof } \\
\text { 1976, } \\
\text { Lambda \& } \\
\text { Tomlinson }\end{array}$ & $\begin{array}{l}\text { Meyerhof } \\
\text { 1976, } \\
\text { Lambda } \\
\text { dan } \\
\text { (Coyle \& } \\
\text { Castello) }\end{array}$ & $\begin{array}{l}\text { Meyerhof } \\
\text { 1976, } \\
\text { Alpha \& } \\
\text { Tomlinson }\end{array}$ & $\begin{array}{l}\text { Meyerhof } \\
1976, \\
\text { Alpha dan } \\
\text { (Coyle \& } \\
\text { Castello) }\end{array}$ & $\begin{array}{l}\text { Meyerhof } \\
\text { 1976, Beta } \\
\text { dan } \\
\text { Tomlinson }\end{array}$ & $\begin{array}{c}\text { Meyerhof } \\
\text { 1976, Beta } \\
\text { dan } \\
\text { (Coyle \& } \\
\text { Castello) }\end{array}$ & $\begin{array}{c}\text { deRuiter } \\
\& \\
\text { Beringen }\end{array}$ & EOID & 3 & 22 \\
\hline $\begin{array}{c}\text { DP04- } \\
07\end{array}$ & 180,58 & 383,65 & 343,33 & 313,45 & 273,13 & 285,10 & 244,78 & 225,78 & 232,00 & 293,80 & 326,80 \\
\hline
\end{tabular}

Tabel Error! No text of specified style in document.. Resume kapasitas tiang ultimit DP06-01

\begin{tabular}{|c|c|c|c|c|c|c|c|c|c|}
\hline \multirow{4}{*}{ Tiang } & \multicolumn{9}{|c|}{ Kapasitas Tiang Ultimit (ton) } \\
\hline & \multicolumn{5}{|c|}{ Teoritis } & \multicolumn{3}{|c|}{ PDA } & \multirow{2}{*}{$\begin{array}{c}\text { Statik } \\
\text { Hari }\end{array}$} \\
\hline & & & Metode & & & & Hari & & \\
\hline & $\begin{array}{c}\text { Meyerhof } \\
1956\end{array}$ & $\begin{array}{c}\text { Meyerhof } \\
1976 \& \& \\
\text { Lambda }\end{array}$ & $\begin{array}{c}\text { Meyerhof } \\
1976 \text { \& } \\
\text { Alpha }\end{array}$ & $\begin{array}{c}\text { Meyerhof } \\
1976 \text { \& Beta }\end{array}$ & $\begin{array}{c}\text { deRuiter \& } \\
\text { Beringen }\end{array}$ & EOID & 3 & 6 & 78 \\
\hline $\begin{array}{c}\text { DP06- } \\
01\end{array}$ & 303,33 & 611,25 & 580,70 & 568,75 & 184,33 & 348,00 & 421,00 & 455,00 & 494,60 \\
\hline
\end{tabular}

Tabel 5. Resume kapasitas tiang ultimit DP06-04

\begin{tabular}{|c|c|c|c|c|c|c|c|c|c|c|c|}
\hline \multirow[b]{4}{*}{ Tiang } & \multicolumn{11}{|c|}{ Kapasitas Tiang Ultimit (ton) } \\
\hline & \multicolumn{8}{|c|}{ Teoritis } & \multicolumn{2}{|c|}{ PDA } & Statik \\
\hline & \multicolumn{8}{|c|}{ Metode } & \multicolumn{2}{|c|}{ Hari } & Hari \\
\hline & $\begin{array}{c}\text { Meyerhof } \\
1956\end{array}$ & $\begin{array}{l}\text { Meyerhof } \\
\text { 1976, } \\
\text { Lambda \& } \\
\text { Tomlinson }\end{array}$ & $\begin{array}{c}\text { Meyerhof } \\
\text { 1976, } \\
\text { Lambda } \\
\text { dan } \\
\text { (Coyle \& } \\
\text { Castello) }\end{array}$ & $\begin{array}{l}\text { Meyerhof } \\
\text { 1976, } \\
\text { Alpha \& } \\
\text { Tomlinson }\end{array}$ & $\begin{array}{c}\text { Meyerhof } \\
1976, \\
\text { Alpha dan } \\
\text { (Coyle \& } \\
\text { Castello) }\end{array}$ & $\begin{array}{c}\text { Meyerhof } \\
\text { 1976, Beta } \\
\text { dan } \\
\text { Tomlinson }\end{array}$ & $\begin{array}{c}\text { Meyerhof } \\
\text { 1976, Beta } \\
\text { dan } \\
\text { (Coyle \& } \\
\text { Castello) }\end{array}$ & $\begin{array}{c}\text { deRuiter } \\
\& \\
\text { Beringen }\end{array}$ & EOID & 4 & 92 \\
\hline $\begin{array}{c}\text { DP06- } \\
04\end{array}$ & 280,90 & 500,66 & 453,21 & 473,24 & 425,80 & 471,88 & 424,43 & 299,71 & 351,10 & 412,80 & 483,50 \\
\hline
\end{tabular}


Tabel 6. Resume kapasitas tiang ultimit DP06-07

\begin{tabular}{|c|c|c|c|c|c|c|c|c|c|c|c|c|}
\hline \multirow[b]{4}{*}{ Tiang } & \multicolumn{12}{|c|}{ Kapasitas Tiang Ultimit (ton) } \\
\hline & \multicolumn{8}{|c|}{ Teoritis } & \multicolumn{3}{|c|}{ PDA } & Statik \\
\hline & \multicolumn{8}{|c|}{ Metode } & \multicolumn{3}{|c|}{ Hari } & Hari \\
\hline & $\begin{array}{c}\text { Meyerhof } \\
1956\end{array}$ & $\begin{array}{c}\text { Meyerhof } \\
\text { 1976, } \\
\text { Lambda \& } \\
\text { Tomlinson }\end{array}$ & $\begin{array}{c}\text { Meyerhof } \\
1976, \\
\text { Lambda } \\
\text { dan } \\
\text { (Coyle \& } \\
\text { Castello) }\end{array}$ & $\begin{array}{c}\text { Meyerhof } \\
\text { 1976, } \\
\text { Alpha \& } \\
\text { Tomlinson }\end{array}$ & $\begin{array}{c}\text { Meyerhof } \\
1976, \\
\text { Alpha } \\
\text { dan } \\
\text { (Coyle \& } \\
\text { Castello) }\end{array}$ & $\begin{array}{c}\text { Meyerhof } \\
\text { 1976, Beta } \\
\text { dan } \\
\text { Tomlinson }\end{array}$ & $\begin{array}{c}\text { Meyerhof } \\
\text { 1976, } \\
\text { Beta dan } \\
\text { (Coyle \& } \\
\text { Castello) }\end{array}$ & $\begin{array}{l}\text { deRuiter } \\
\quad \& \\
\text { Beringen }\end{array}$ & EOID & 3 & 5 & 44 \\
\hline $\begin{array}{c}\text { DP06- } \\
07\end{array}$ & 406,11 & 762,89 & 736,91 & 753,81 & 727,82 & 716,50 & 690,51 & 584,81 & 327,60 & 438,40 & 425,90 & 425,40 \\
\hline
\end{tabular}

Tabel 7. Resume kapasitas tiang ultimit SP-01

\begin{tabular}{|c|c|c|c|c|c|c|c|c|c|c|c|c|c|}
\hline \multirow{4}{*}{ Tiang } & \multicolumn{13}{|c|}{ Kapasitas Tiang Ultimit (ton) } \\
\hline & \multicolumn{8}{|c|}{ Teoritis } & \multicolumn{4}{|c|}{ PDA } & Statik \\
\hline & \multicolumn{8}{|c|}{ Metode } & \multicolumn{4}{|c|}{ Hari } & Hari \\
\hline & $\begin{array}{c}\text { Meyerhof } \\
1956\end{array}$ & $\begin{array}{c}\text { Meyerhof } \\
\text { 1976, } \\
\text { Lambda \& } \\
\text { Tomlinson }\end{array}$ & $\begin{array}{l}\text { Meyerhof } \\
\text { 1976, } \\
\text { Lambda dan } \\
\text { (Coyle \& } \\
\text { Castello) }\end{array}$ & $\begin{array}{c}\text { Meyerhof } \\
\text { 1976, } \\
\text { Alpha \& } \\
\text { Tomlinson }\end{array}$ & $\begin{array}{l}\text { Meyerhof } \\
\text { 1976, } \\
\text { Alpha dan } \\
\text { (Coyle \& } \\
\text { Castello) }\end{array}$ & $\begin{array}{l}\text { Meyerhof } \\
\text { 1976, Beta } \\
\text { dan } \\
\text { Tomlinson }\end{array}$ & $\begin{array}{c}\text { Meyerhof } \\
\text { 1976, } \\
\text { Beta dan } \\
\text { (Coyle \& } \\
\text { Castello) }\end{array}$ & $\begin{array}{c}\text { deRuiter } \\
\& \\
\text { Beringen }\end{array}$ & EOID & 1 & 3 & 7 & 29 \\
\hline SP-01 & 567,02 & 538,14 & 510,33 & 507,64 & 479,83 & 502,63 & 474,83 & 475,30 & 597,20 & 715,90 & 724,10 & 725,30 & 679,40 \\
\hline
\end{tabular}

Tabel 8. Resume kapasistas tiang ultimit SP-04

\begin{tabular}{|c|c|c|c|c|c|c|c|c|c|c|c|c|c|}
\hline \multirow{4}{*}{ Tiang } & \multicolumn{13}{|c|}{ Kapasitas Tiang Ultimit (ton) } \\
\hline & \multicolumn{8}{|c|}{ Teoritis } & \multicolumn{4}{|c|}{ PDA } & Statik \\
\hline & \multicolumn{8}{|c|}{ Metode } & \multicolumn{4}{|c|}{ Hari } & Hari \\
\hline & $\begin{array}{c}\text { Meyerhof } \\
1956\end{array}$ & $\begin{array}{c}\text { Meyerhof } \\
\text { 1976, } \\
\text { Lambda \& } \\
\text { Tomlinson }\end{array}$ & $\begin{array}{c}\text { Meyerhof } \\
\text { 1976, } \\
\text { Lambda } \\
\text { dan (Coyle } \\
\text { \& Castello) }\end{array}$ & $\begin{array}{c}\text { Meyerhof } \\
\text { 1976, } \\
\text { Alpha \& } \\
\text { Tomlinson }\end{array}$ & $\begin{array}{c}\text { Meyerhof } \\
\text { 1976, } \\
\text { Alpha } \\
\text { dan } \\
\text { (Coyle \& } \\
\text { Castello) }\end{array}$ & $\begin{array}{c}\text { Meyerhof } \\
\text { 1976, Beta } \\
\text { dan } \\
\text { Tomlinson }\end{array}$ & $\begin{array}{c}\text { Meyerhof } \\
\text { 1976, } \\
\text { Beta dan } \\
\text { (Coyle \& } \\
\text { Castello) }\end{array}$ & $\begin{array}{c}\text { deRuiter } \\
\& \\
\text { Beringen }\end{array}$ & EOID & 1 & 3 & 7 & 24 \\
\hline SP-04 & 564,27 & 897,31 & 869,50 & 862,30 & 834,49 & 896,29 & 868,49 & 638,08 & 588,80 & 547,60 & 600,70 & 616,70 & 525,00 \\
\hline
\end{tabular}

\section{Analisis peningkatan daya dukung}

Prediksi peningkatan daya dukung pada tujuh tiang dihitung menggunakan rumus yang dikemukakan oleh Skov \& Denver (1988). Hasil perhitungan dapat dilihat pada Tabel 9.

Tabel 9. Hasil analisis peningkatan daya dukung tiang Metode Skov \& Denver 1988

\begin{tabular}{cccccccc}
\hline \multirow{2}{*}{ Tiang } & \multicolumn{7}{c}{ Prediksi Daya Dukung (ton) } \\
\cline { 2 - 8 } & EOID & 1 Hari & 3 Hari & 4 Hari & 5 Hari & 6 Hari & 7 Hari \\
\hline DP04-04 & 220,00 & - & 282,98 & - & - & 322,72 & - \\
\hline DP04-07 & 232,00 & - & 298,42 & - & - & - & - \\
\hline DP06-01 & 348,00 & - & 447,62 & - & 493,94 & - & - \\
\hline DP06-04 & 351,00 & - & - & 477,79 & - & - & - \\
\hline DP06-07 & 328,00 & - & 421,90 & - & 465,56 & - & - \\
\hline SP-01 & 597,20 & 597,20 & 768,16 & - & - & - & 900,02 \\
\hline SP-04 & 588,80 & 588,80 & 757,36 & - & - & - & 887,36 \\
\hline
\end{tabular}




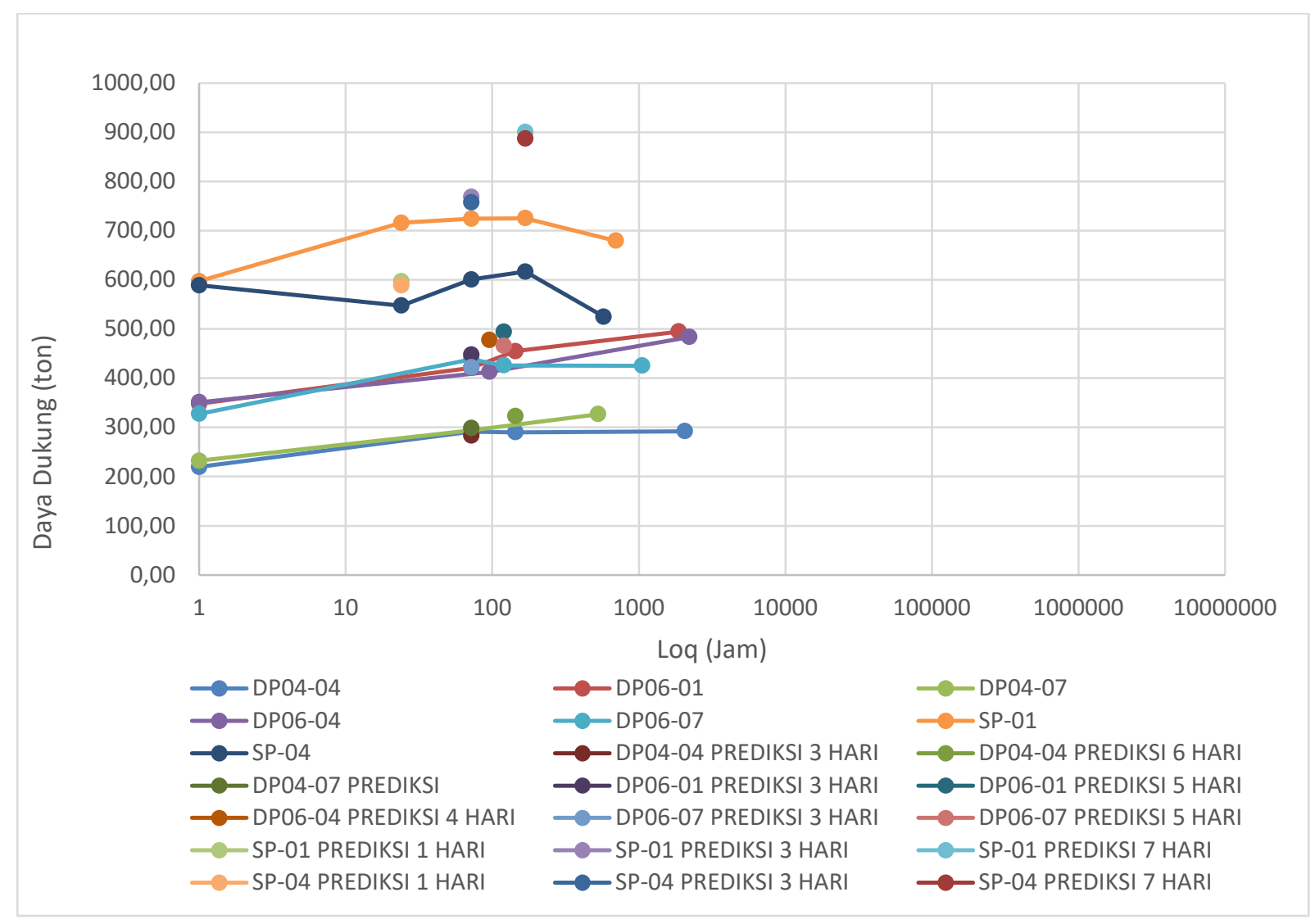

Gambar 2. Kurva Prediksi Daya Dukung Tiang

Dari Gambar 2 dapat dilihat bahwa rumus prediksi peningkatan daya dukung tiang yang dikeluarkan oleh Skov \& Denver masih bisa digunakan pada tanah di daerah Cirebon, dikarenakan selisih dengan peningkatan daya dukung aktual tidak berbeda jauh, selisih nya berada pada kisaran 1-15\%.

\section{Grafik daya dukung teoritis dengan pembebanan aktual lapangan}

Setelah daya dukung teoritis dan pengujian pembebanan di lapangan dibandingkan, maka dapat dilihat pola transfer beban daya dukung teoritis yang mendekati hasil pengujian di lapangan. Kemudian ketiganya akan di plot kedalam grafik yang sama terhadap waktu untuk melihat besaran peningkatan daya dukung. 


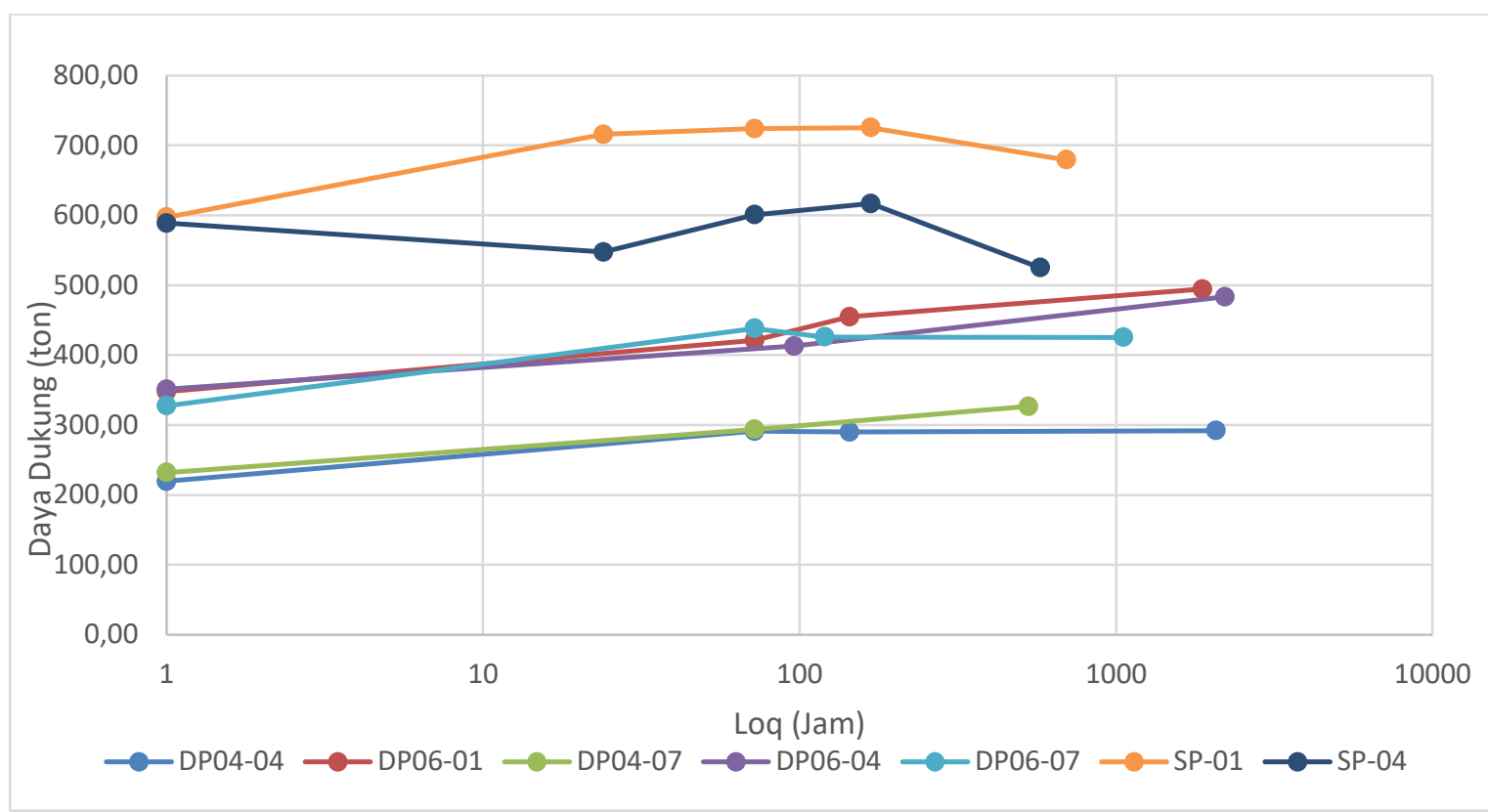

Gambar 1. Kurva peningkatan daya dukung terhadap waktu

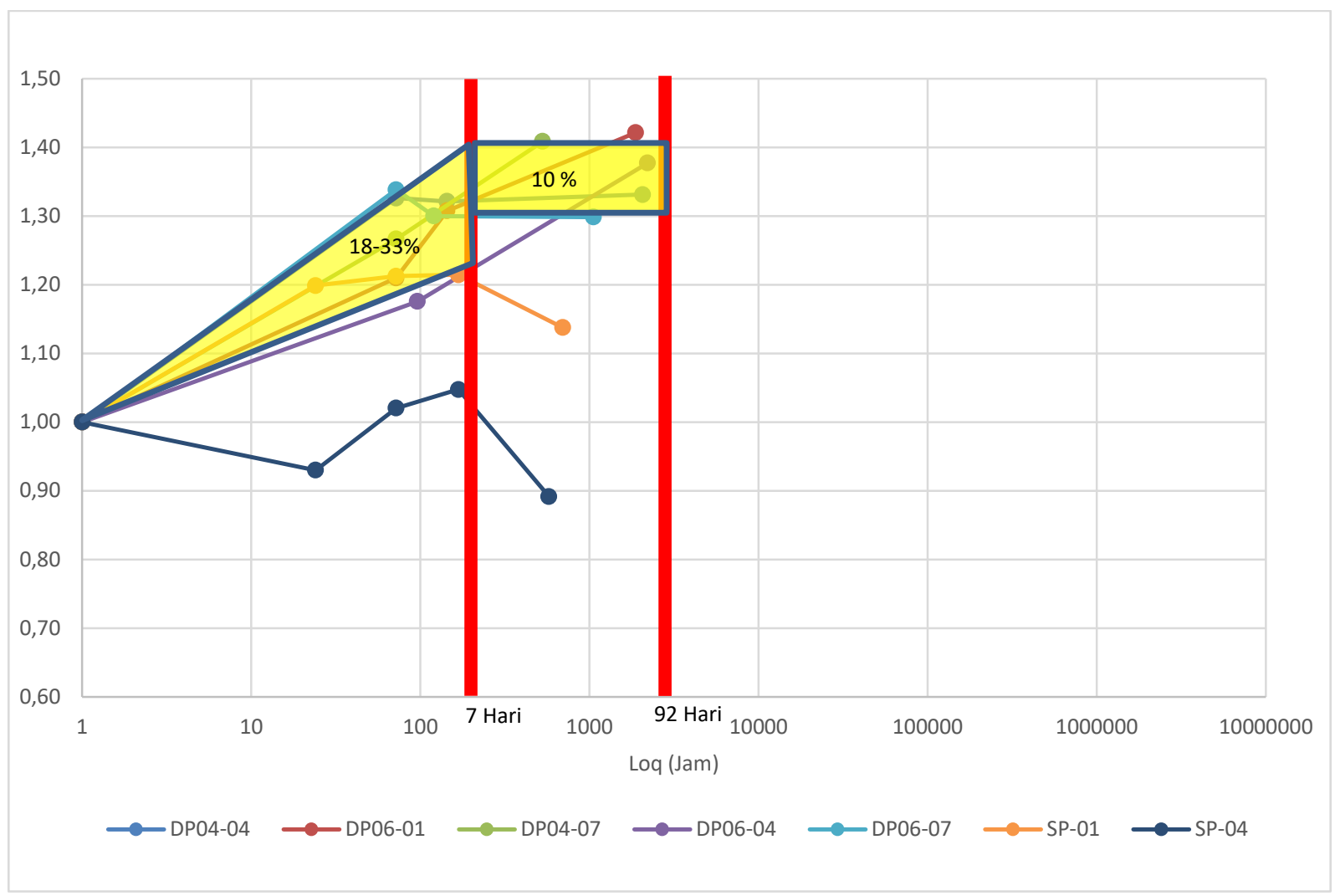

Gambar Error! No text of specified style in document.. Normalized kurva peningkatan daya dukung terhadap waktu

Dapat dilihat pada Gambar 3. tiang yang ada baik diameter 400mm, 600mm, dan $762 \mathrm{~mm}$ terkecuali tiang SP-04, memiliki kenaikan nilai daya dukung pada rentang waktu setelah pemancangan sampai dengan 7 hari setelah pemancangan. Dan setelah 7 hari pemancangan hingga dilakukannya pembebanan statik. 
Besaran peningkatan yang terjadi dapat dilihat pada kurva yang telah di Normalized, Gambar 4. Normalized data pada kurva dilakukan dengan membagi masing masing daya dukung tiang dengan daya dukung ultimit tiang berdasarkan uji pembebanan dinamik setelah pemancangan. Besaran peningkatan daya dukung yang terjadi sebesar 18-33\% dari sesaat setelah pemancagan hingga 7 hari setelah pemancangan. Kemudian terjadi peningkatan sebesar 10\% pada rentang waktu 7 hari hingga 92 hari setelah pemancangan.

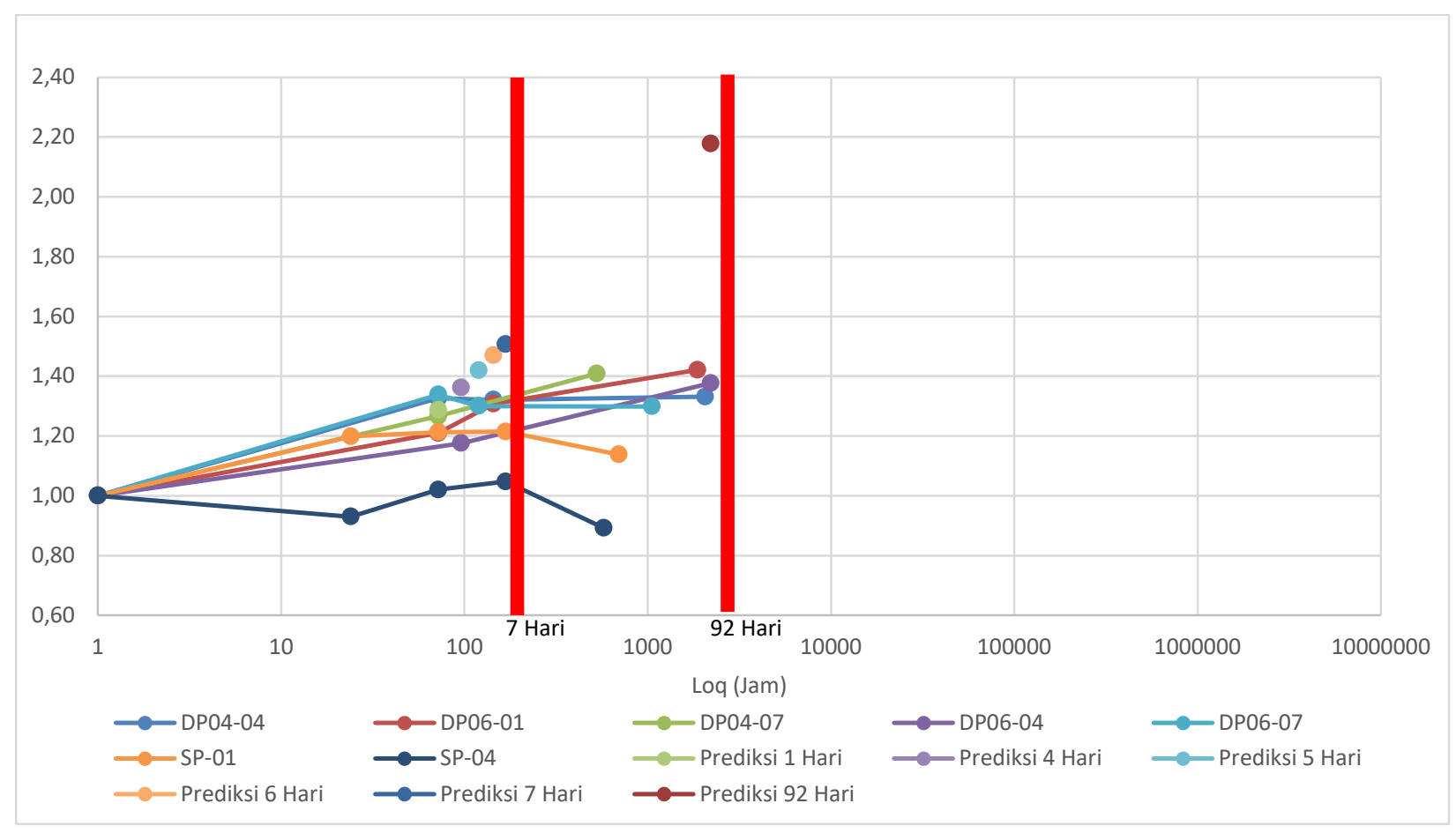

Gambar 5. Normalized Kurva Analisis Daya Dukung dan Prediksi Peningkatan Daya Dukung

Dari Gambar 5. terlihat bahwa kombinasi rumus yang dipakai pada perhitungan analisis daya dukung menunjukan pola yang memiliki kecenderungan mendekati daya dukung statik maupun dinamik. Prediksi daya dukung menunjukan data yang sesuai dengan hasil pengujian di lapangan sehingga peningkatan daya dukung dari pemancangan hingga 92 hari berkisar $40 \%$.

\section{KESIMPULAN}

Berdasarkan analisis data dan pembahasan yang telah dilakukan dari pembangunan proyek pembangkit listrik di Cirebon, Jawa Barat dapat dihasilkan kesimpulan sebagai berikut:

1. Adanya peningkatan daya dukung tiang pancang akibat faktor soil setup, baik pada daya dukung ujung tiang maupun daya dukung selimut tiang.

2. Besaran peningkatan daya dukung pada tiang spun pile dan steel pipe pile berkisar 18-33\% pada jangka waktu 7 hari, dan meningkat 10\% pada rentang waktu 7 hingga 92 hari.

3. Peningkatan daya dukung pada tiang spun pile dan steel pipe pile pada tanah Cirebon meningkat sebesar 40\% selama 92 hari.

4. Rumus pendekatan peningkatan daya dukung tiang yang dikemukakan oleh Skov \& Denver dapat digunakan pada kondisi tanah Cirebon.

5. Perhitungan teoritis daya dukung tiang pancang berdasarkan kombinasi rumus Meyerhof 1976, Lambda, Alpha, Beta, Tomlinson dan Coyle Castello dapat dipergunakan dalam kondisi tanah di daerah Cirebon dan menurut pola yang ada, daya dukung yang masih menjauhi pengujian beban statik maupun dinamik akan mencapai daya dukung teoritis dalam jangka panjang. 


\section{DAFTAR PUSTAKA}

Coyle, Harry M., Reno R. Castello. (1981). “New Design Correlations for Piles in Sand”. Journal of Geotechnical and Geoenvironmental Engineering 107.ASCE 16379.

Meyerhof G.G. (1976). "Bearing Capacity and Settlement of Pile Foundations”, ASCE: Journal Geotechnical and Geoenvironmental Engineering Division. Vol. 102, No. GT 3.

Mulyono, T., S. Musalamah., and N. Hanifah. (2018). “Aktualisasi Kapasitas Daya Dukung Aksial Pondasi Tiang Pancang Berdasarkan Parameter Tanah dan Static Loading Test”. Jurnal Kajian Teknil Sipil Volume 3 No.1.

Rahardjo, Paulus P. (2013) "Manual Pondasi Tiang, Edisi 4”. Bandung: DFRI Universitas Parahyangan.

Schwab, Klaus. (2017) “The Global Competitiveness Report 2017-2018”. Geneva: World Economic Forum.

Skov, Rikard, and Hans Denver. (1988). “Time-Dependence of Bearing Capacity of Piles”. Proc. Third International Conference on the Application of Stress-Wave Theory to Piles. Ottawa.

Standar Nasional Indonesia 8460:2017 tentang Persyaratan Perancangan Geoteknik.

Tomlinson, M.J. (1994). Pile Design and Construction Practice. $4^{\text {th }}$ Edition. London: E\&FN Spon.

Widjaja, Budianto. (2007). "Peningkatan Daya Dukung Pondasi Tiang Pancang Pada Tanah Pasiran dan Kelempungan Studi Kasus Porto dan Jakarta”. Media Komunikasi Teknik Sipil. Tahun 15, No.2. 